\title{
МУЛЬТИБИОКОНВЕРСИОННЫЕ ТВЕРДОФАЗНЫЕ БИОПРЕПАРАТЫ НОВОГО ПОКОЛЕНИЯ НА ОСНОВЕ Bacillus subtilis И Trichoderma asperellum ПОВЫШАЮТ ЭФФЕКТИВНОСТЬ ЗАЩИТЫ КАРТОФЕЛЯ ОТ ФИТОФТОРОЗА*
}

\author{
Ю.А. ТИТОВА, И.И. НОВИКОВА, И.В. БОЙКОВА, В.А. ПАВЛЮШИН, \\ И.Л. КРАСНОБАЕВА
}

Против болезней картофеля в России в настоящее время используют 17 биопрепаратов на основе штаммов-продуцентов Bacillus subtilis и Trichoderma asperellum (=T. harzianum). В мире накоплен большой опыт получения и применения традиционных сухих и жидких препаративных форм промышленных биопрепаратов. Однако недостаточны сведения об эффективности форм, разрабатываемых на основе мультибиоконверсии техногенных отходов, что актуально в связи с экологической значимостью этой проблемы и поиском ресурсов дешевого и доступного сырья. Настоящая работа представляет успешный опыт использования растительных отходов в качестве субстрата при выращивании съедобных грибов, а затем микробных штаммов и получения гранулированных антифунгальных биопрепаратов. Это актуальный подход к биотехнологиям более безопасного использования отходов и превращения их в полезные продукты. Цель исследования получить экспериментальные образцы принципиально новых мультибиоконверсионных препаратов на основе микробов-антагонистов для защиты картофеля от болезней и оценить их эффективность. Технология включала мультибиоконверсию растительных отходов (смесь опилок с пшеничными отрубями) посредством выращивания последовательно Lentinula edodes (Berk.) Pegler (шиитаке) и Pleurotus ostreatus (Jacq.: Fr.) P. Kummer HK-35 (вешенка), а затем штаммовпродуцентов B. subtilis B-10 и T. asperellum T-36. Оценка питательной ценности субстрата, полученного в результате разложения целлюлозы и лигнина из первичной смести отходов, выявила более высокое содержание белка $(9,4 \pm 0,3$ против $2,7 \pm 0,3$ и 4,3 $\pm 0,1 \%)$ и азота $(1,5 \pm 0,3$ против $0,4 \pm 0,1$ и $0,6 \pm 0,1 \%)$, а также пониженное соотношение $C: N(38,3$ против 81,2 и 92,9) по сравнению с субстратом, обычно используемым для выращивания шиитаке, или с торфом как одним из субстратов для твердофазной ферментации. Жидкий инокулюм штаммов-продуцентов получали на стандартных питательных средах Чапека (ОOO «Биокомпас-С», Россия) и кукурузномелассовой («Каргилл», ООО «Агроресурс», Россия). При твердофазной ферментации дважды (мульти-) биоконвертированный субстрат (последовательное выращивание шиитаке и вешенки) инокулировали B. subtilis В-10 (0,9×109 сп/мл) и T. asperellum Т-36 $\left(2,8 \times 10^{10}\right.$ КОЕ/мл) и культивировали в течение 10 сут при $25-28{ }^{\circ}$ С. Лабораторные образцы биопрепаратов тестировали в полевых условиях на картофеле сорта Елизавета (ПК «Шушары», Ленинградская обл., 2011 год). Применили взаимоортогональную организацию полевого опыта со сплошным размещением вариантов в 4-кратной повторности на площади 0,5 га; площадь учетной делянки -10 м², общий объем выборки - 482 растения. Препараты применяли 1-кратно: при посадке (12 мая 2011 года) клубни перемешивали в бункере картофелесажающего агрегата с твердофазными мультиковерсионными биопрепаратами при норме расхода в каждом варианте 1 кг на 1,5 т клубней (2 кг/га). Препараты сочетали с базовыми агротехническими и защитными мероприятиями, используемыми при выращивании сорта. Они включали послепосадочную обработку почвы гербицидом Sencor® (Зенкор Ультра, КС, 800 г/л; «Вауer Crop Science», Германия); послевсходовые 2-кратные (интервал 1 нед) внесения комплексного минерального препарата Terraflex® (Террафлекс 17/17/17, I, 2,8 и 1,6 кг/га; «Nu3 N.V.», Бельгия); послевсходовые 1-кратные внесения содержащего микро- и мезоэлементы комплекса Аквадон микро (2,0 л/га; «Оргполимерсинтез», Россия), микробиологического удобрения Экстрасола ${ }^{\circledR}$ (2 л/га; «Бисолби-Интер», Россия), стимулятора роста Циркон, Р (0,1 г/л; 10 г/га; АНО «НЭСТ М», Россия) и обработки гербицидами Лазурит Т, СП (700 г/кг; 0,5 л/га; АО «Август», Россия) и Titus ${ }^{\text {тм }}$ (Титус, CTC, 250 г/кг; 20 г/га; «DuPont», США); также после смыкания рядков растения обрабатывали фунгицидами: Bravo® (Браво, КС, 500 г/л; 1,5 л/га; «Syngenta AG», Швейцария) и Ridomil gold® (Ридомил Голд, ВДГ, 640 + 40 г/кг; 1,5 л/га; «Syngenta AG», Швейцария) - через 2 нед, Revus® (Ревус, KC, 250 г/л; 250 г/га; «Syngenta AG», Швейцария) - через 4 нед и Shirlan ${ }^{\circledR}$ (Ширлан, CK, 500 г/л; 0,4 л/га; «Syngenta AG», Швейцария) - через 6 нед. Последнюю подкормку Террафлекс финал $(2,8$ кг/га) в сочетании с обработкой Ширлан, СК (0,4 л/га) проводили за 2 нед до уборки урожая. Вариант без применения биопрепаратов служил контролем. Использовали стандартные методы учета урожайности, биометрических (рост, облиственность) и фитопатологических (распространенность и развитие болезней) показателей, статистической обработки результатов (расчеты средних и их стандарт-

* Работа выполнена в рамках КПНИ «Развитие селекции и семеноводства картофеля»: раздел 9 «Разработка эффективных технологий защиты картофеля». 
ных ошибок, дисперсионный анализ ANOVA). Статистическую значимость различий оценивали по $\boldsymbol{t}$-критерию Стьюдента для попарного сравнения вариантов. Биометрические учеты с фиксацией появления симптомов заболеваний проводили на 3-недельных проростках (1-2-й ярус листьев) и при смыкании рядков, два фитопатологических учета - в начале и в конце цветения; финальный учет выполняли при сборе урожая клубней. Результаты полевых испытаний свидетельствуют, что при дополнении стандартной агротехнологии обработкой полученными мультиконверсионными биопрепаратами в начале вегетации достоверно увеличивалась скорость роста и облиственности растений картофеля. Урожай здоровых клубней при применении биопрепаратов на основе штаммов $B$. subtilis В-10 и $T$. asperellum T-36 был достоверно $($ р $\leq 0,10)$ выше контроля соответственно на 240 и 690 г/м². Развитие фитофтороза также достоверно $(\mathrm{p} \leq 0,01)$ снизилось (соответственно в 7,2 и 11,6 раза). По сравнению с контролем масса пораженных клубней, в том числе с признаками вторичной бактериальной инфекции, достоверно (p $\leq 0,01)$ уменьшилась почти в 2,0 раза (соответственно на 140 и 130 г/м²). Таким образом, мультибиоконверсия твердых растительных отходов перспективна при производстве гранулированных экологически безопасных биопрепаратов для защиты растений от болезней. В разработанной нами трехступенчатой технологии отходы бикультуры съедобных грибов на опилках, смешанных с пшеничными отрубями, обладают высокой питательной ценностью в качестве субстрата для твердофазного культивирования микроорганизмов.

Ключевые слова: биологическая эффективность биопрепаратов, биопрепараты для защиты картофеля от болезней, микробы-антагонисты, мультиконверсионные биопрепараты, Bacillus subtilis, Trichoderma asperellum.

В 2019 году в России для защиты картофеля от болезней разрешены 17 биопрепаратов (Государственный каталог пестицидов и агрохимикатов, разрешенных к применению на территории Российской Федерации. М., 2019). Большинство из них (13 препаратов) разработаны на основе бактерий, 11 - это продукты жидкофазного культивирования продуцентов Bacillus subtilis (Ehren.) Cohn, 3 - получены при жидкофазном и последовательном жидкофазно-твердофазном культивировании штаммов Trichoderma asperellum Samuels, Lieckf. \& Nirenberg (= Trichoderma harzianum) (1). Эти виды и штаммы микроорганизмов характеризуются большим разнообразием метаболических процессов, неприхотливы при культивировании, высокотехнологичны и обладают экологической пластичностью (2-5). Сложные комплексы биологически активных веществ (БАВ) различного спектра действия определяют их бактерицидную, фунгицидную или гиперпаразитическую (для Trichoderma spp.) активность (6-8). Ряд метаболитов микроорганизмов проявляют ростостимулирующий эффект и ускоряют рост и развитие растений, а некоторые способны повышать их неспецифическую болезнеустойчивость $(9,10)$. Особенности вторичного метаболизма штаммов B. subtilis и T. asperellum обусловливают полифункциональность препаративных форм на их основе $(11,12)$.

Биопрепараты получают различными методами. Глубинное культивирование считается более технологичным, так как контролируемые условия процесса ферментации позволяют получать стандартизованный конечный продукт. Такие технологии включают ряд операций по концентрированию и сушке, что повышает их затратность, кроме того, для проявления биологического эффекта таких препаратов требуется более длительное время. Спорообразующие бактерии неприхотливы к условиям культивирования, их споры выдерживают технологический этап сушки без потери жизнеспособности и биологической активности. Штаммы микромицетов, образуя обильную биомассу при глубинном культивировании, плохо формируют конидии в жидкой среде (18). При ферментации на твердом субстрате программа конидиогенеза у микромицетов реализуется в полной мере (13).

Твердофазная ферментация при получении биопрепаратов позволяет решать проблему ресурсов дешевого и доступного сырья для промышленных биотехнологий за счет использования растительных отходов техногенной сферы (14). Биопрепараты, полученные на растительных суб- 
стратах, позволяют продуцентам более длительный период сохраняться как в препаративной форме, так и после применения - в почвенной микробиоте (14). Техногенные растительные отходы (лесо-, деревоперерабатывающая промышленность, коммунальное, лесное и сельское хозяйство), содержащие трудно утилизируемый большинством микроорганизмов лигноцеллюлозный комплекс, наиболее эффективно используются лишь в промышленном производстве съедобных грибов (15-17). Только ксилотрофные базидиальные макромицеты способны полностью разлагать лигноцеллюлозные субстраты и обогащать малоценные грубые растительные отходы грибным белком, легкоусвояемыми углеводами, витаминами и минеральными компонентами, тем самым обеспечивая возможность использования таких субстратов в различных биотехнологических процессах (1821). Пронизанный мицелием переработанный субстрат после съема плодовых тел и завершения технологического цикла в промышленном грибоводстве возвращается в окружающую среду в виде органических отходов и может использоваться в качестве кормовых добавок, удобрений или для выращивания других съедобных грибов и микроорганизмов с различной целевой активностью (22-24).

Использование отходов культивирования съедобных грибов в качестве субстратной основы, содержащей дешевые, доступные источники питания и набор микроэлементов, необходимый для обеспечения быстрого роста и развития культур микроорганизмов, рассматривается как один из перспективных подходов при производстве биопрепаратов $(25,26)$. В последнее время возрос интерес к разработкам принципиально новых многостадийных, безотходных, ресурсосберегающих и экологически безопасных технологий биоконверсии отходов техногенной сферы с использованием ряда высших базидиальных макромицетов и штаммов - продуцентов биопрепаратов (27). В мире накоплен большой опыт по производству жидко- и твердофазной ферментацией на растительных субстратах (торфе) и повышению эффективности промышленных биопрепаратов на основе штаммов-продуцентов B. subtilis и T. asperellum $(28,29)$, в том числе применяемых против болезней картофеля $(30,31)$. Однако отметим, что при этом нигде в мире не используют мультиконвертированные отходы техногенной сферы в качестве субстратов для производства биопрепаратов. Недостаточны сведения о получении и эффективности препаративных форм, разрабатываемых на основе многоступенчатой (мульти-) биоконверсии отходов техногенной сферы и сельского хозяйства (32).

В настоящей работе впервые представлены данные об успешном применении принципиально нового подхода - направляемой мультибиоконверсии отходов в полезные продукты, а именно многократное использование растительных отходов в бикультуре съедобных грибов в промышленном грибоводстве и для получения гранулированных антифунгальных биопрепаратов. Мультибиоконверсия растительных техногенных и сельскохозяйственных отходов проходила при последовательном культивировании грибов Lentinula edodes (Berk.) Pegler (шиитаке), Pleurotus ostreatus (Jacq.: Fr.) P. Kummer HK-35 (вешенка) и штаммов-продуцентов Bacillus subtilis B-10 и Trichoderma asperellum Т-36. Показана повышенная питательная ценность конвертированных отходов относительно традиционно применяемых субстратов. Применение полученных нами экспериментальных лабораторных образцов биопрепаратов в полевых условиях против фитофтороза картофеля повысило эффективность защитных мероприятий на 70-75\% относительно базовых агротехнических и защитных мероприятий.

Цель исследования - разработать способ получения мультиконвер- 
сионных биопрепаратов на основе антагонистов фитопатогенов и оценить защитное действие таких биопрепаратов при выращивании картофеля.

Методика. Основой для гранулированных мультиконверсионных биопрепаратов служили коллекционные штаммы-продуценты Bacillus subtilis В-10 и Trichoderma asperellum Т-36 (Государственная коллекция микроорганизмов, патогенных для растений и их вредителей, Центр коллективного пользования научным оборудованием «Инновационные технологии защиты растений» ФГБНУ ВИЗР; коллекция зарегистрирована 28 января 1998 года под № 760 в World Federation for Culture Collections, World Data Centre for Microorganisms - WFCC WDCM, Япония). Производитель промышленного мицелия шиитаке Lentinula edodes (Berk.) Pegler (летний гибрид) и вешенки Pleurotus ostreatus (Jacq.: Fr.) P. Kummer HK-35 (бесшоковый гибрид) - фирма «Sylvan Hungaria Zrt.» (Венгрия).

Субстрат KLePo (C3) для последующего твердофазного культивирования микроорганизмов по мультибиоконверсионной технологии получали 2-ратной конверсией промышленного субстрата для культивирования шиитаке ПLе (C1) на основе растительных отходов - опилок дубовых $(88,9 \%)$ и отрубей пшеничных $(10 \%)$ с добавлением $\mathrm{CaCO}_{3}(0,1 \%)$ и $\mathrm{CaSO}_{4} \cdot 2 \mathrm{H}_{2} \mathrm{O}$ (1\%) (по массе при $70 \%$ влажности смеси). На простерилизованном С1 (П $L e)$ методом полупромышленного малообъемного глубинно-твердофазного культивирования выращивали сначала шиитаке (3 мес при $18-23{ }^{\circ} \mathrm{C}$ и влажности воздуха 85-95 \%), получали плодовые тела и отработанный субстрат (C2), а затем на С2 культивировали вешенку (2 мес при 20-22 ${ }^{\circ} \mathrm{C}$ и влажности воздуха 85-95 \%) и так же получали плодовые тела и субстрат C3, полностью пронизанный мицелием этих грибов. Состав С3 (отходы культивирования съедобных базидиомицетов) охарактеризовали по питательной ценности (содержание полисахаридов, белка, общего и аминного азота, аминокислот, витаминов и микроэлементов), сравнив с образцами промышленного субстрата для культивирования шиитаке $(\mathrm{C} 1-\Pi L e)$ и низинного торфа (используется при производстве биопрепаратов на торфяной основе). Анализы выполнены в Испытательной лаборатории ФГБНУ АФИ (г. Санкт-Петербург) в соответствии с ГОСТ 26177-84 (система Fibertec 8000), ГОСТ 51417-99 (система Digestor 2520), ГОСТ 31675-2012 (система Fibertec) (все системы фирмы «Foss Tecator», Швеция); ГОСТ 32903-2014 (жидкостный хроматограф Стайер, «Аквилон», Россия); ГОСТ 15962-2014 (атомно-абсорбционный спектрометр АА 240, «Varian Techtron Pty Ltd», Австралия); ГОСТ 15607-2015 и ГОСТ 34230-2017 (жидкостный хроматограф Стайер, «Аквилон», Россия).

Инокулюм T. asperellum Т-36 (первая стадия технологического процесса производства биопрепарата) получали культивированием в стандартной жидкой синтетической среде Чапека $\left(\mathrm{NaNO}_{3}-2\right.$ г/л, $\mathrm{KH}_{2} \mathrm{PO}_{4}-$ 1 г/л, $\mathrm{MgSO}_{4}-0,5$ г/л, $\mathrm{KCl}-0,5$ г/л, $\mathrm{FeSO}_{4}-0,01$ г/л, глюкоза - 20 г/л; $\mathrm{pH}=7,0)\left(\mathrm{OOO}\right.$ «Биокомпас-С», Россия) при $24-26{ }^{\circ} \mathrm{C}$ в течение 5 сут с аэрацией (250 об/мин, шейкер-инкубатор New Brunswick ${ }^{\mathrm{TM}}$ Innova ${ }^{\circledR} 44$, «Eppendorf», Германия). Штамм B. subtilis В-10 выращивали в оптимизированной кукурузно-мелассовой среде (кукурузный экстракт - 30 г/л, меласса - 15 г/л; рН = 7,8) («Каргилл», ООО «Агроресурс», Россия) при 27-28 ${ }^{\circ} \mathrm{C}$ в течение 3 сут с аэрацией (150 об/мин, шейкер-инкубатор New Brunswick $^{\mathrm{TM}}$ Innova $\left.{ }^{\circledR} 44\right)$. Титры полученных инокулюмов определяли методом серийных разведений с высевом на агаризованные среды (агар Чапека, «HiMedia Laboratories», Индия; сухой питательный агар СПА, АO «НПО «Микроген», Россия). Для T. asperellum Т-36 титр составил

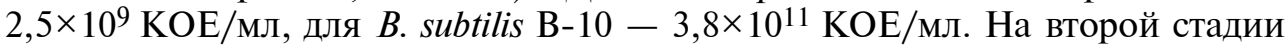


(твердофазное культивирование микроорганизмов) каждым из штаммов инокулировали С3 (T. asperellum Т-36 - в дозе $2,8 \times 10^{10} \mathrm{KOE} /$ мл, B. subtilis В-10 - в дозе $0,9 \times 10^{9}$ спор/мл). Твердофазное культивирование штаммовпродуцентов проводили в течение 10 сут при $25-28{ }^{\circ} \mathrm{C}$ в условиях термостатированной камеры (лабораторный термостат ПРО ТС 30/120-500, НПО «Прооборудование», Россия).

Питательные среды и субстраты стерилизовали автоклавированием (5075ELVPV D, «Tuttnauer Europe B.V.» Нидерланды).

Экспериментальные образцы мультиконверсионных биопрепаратов тестировали в полевых условиях (ПК «Шушары», Ленинградская обл.) на столовом сорте картофеля Елизавета (среднеранний, высокоурожайный, со средней устойчивостью к фитофторозу, выведен для условий Центрального, Северо-Кавказского, Северо-Западного, Северного, Волго-Вятского и Дальневосточного регионов России, районирован в Северо-Западном регионе; оригинаторы - Северо-Западный НИИ сельского хозяйства и Всеволожская селекционная станция).

Препараты применяли 1-кратно при посадке (12 мая 2011 года). Клубни перемешивали с биопрепаратами в бункере картофелесажающего агрегата при норме расхода 1 кг на 1,5 т клубней (2 кг/га засеваемой площади). Посадку проводили в утреннее время при температуре $17{ }^{\circ} \mathrm{C}$ и относительной влажности воздуха $72 \%$. Препараты сочетали с базовыми агротехническими и защитными мероприятиями, принятыми в хозяйстве (в контроле биопрепараты исключали). Площади участков по вариантам опыта и в контроле - по 0,5 га. Базовые агротехнические и защитные мероприятия включали послепосадочную обработку почвы гербицидом Sencor® (Зенкор Ультра, КС, 800 г/л; «Bayer Crop Science», Германия); послевсходовые 2-кратные (интервал 1 нед) внесения комплексного минерального препарата Terraflex® (Террафлекс 17/17/17, П, 2,8 и 1,6 кг/га); «Nu3 N.V.», Бельгия); послевсходовые 1-кратные внесения содержащего микро- и мезоэлементы комплекса Аквадон микро (2,0 л/га; «Оргполимерсинтез», Россия), микробиологического удобрения Экстрасола® (2 л/га; «Бисолби-Интер», Россия), стимулятора роста Циркон, Р (0,1 г/л; 10 г/га; АНО «НЭСТ М», Россия) и обработки гербицидами Лазурит Т, СП (700 г/кг; 0,5 л/га; АО «Август», Россия) и Titus $^{\text {тм }}$ (Титус, СТС, 250 г/кг; 20 г/га; «DuPont», США); также после смыкания рядков растения обрабатывали фунгицидами: Bravo® (Браво, КС, 500 г/л; 1,5 л/га; «Syngenta AG», Швейцария) и Ridomil gold® (Ридомил Голд, ВДГ, $640+40$ г/кг; 1,5 л/га; «Syngenta AG», Швейцария) - через 2 нед, Revus® (Ревус, KC, 250 г/л; 250 г/га; «Syngenta AG», Швейцария) - через 4 нед и Shirlan® (Ширлан, CK, 500 г/л; 0,4 л/га; «Syngenta AG», Швейцария) - через 6 нед. Последнюю подкормку Террафлекс финал (2,8 кг/га) в сочетании с обработкой Ширлан, CK (0,4 л/га) проводили за 2 нед до уборки урожая (5 сентября 2011 года).

Для оценки эффективности образцов биопрепаратов применили взаимоортогональную схему полевого опыта со сплошным размещением организованных повторений вариантов: 4 повторности, площадь учетной делянки $10 \mathrm{м}^{2}$, общий объем выборки - 482 растения (33). Для оценки роста растений и поражения фитофторозом использовали стандартные биометрические и фитопатологические показатели (скорость роста растений и их облиственность, распространенность и развитие болезни, потери урожая, абсолютная биологическая эффективность препарата и биологическая эффективность относительно контроля) (34). Результаты полевых испытаний регистрировали в пять этапов: два биометрических учета с фиксацией появления симптомов заболеваний проводили на 3-4-недель- 
ных проростках картофеля в фазу 1-2-го ярусов листьев и при смыкании рядков на 6-7-недельных растениях в фазу 9-10-го ярусов листьев; два фитопатологических учета развития болезней выполняли в начале и в конце цветения культуры (соответственно 19 июля и 16 августа 2011 года); один учет осуществляли при сборе урожая клубней 5 сентября 2011 года (35). Учет урожая картофеля проводили разбросанным размещением организо-

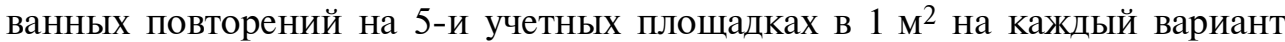
опыта и контроля $(33,35)$.

Статистическая обработка полученных результатов с использованием пакетов программ Microsoft Excel 2010 и Statistica 6.0 («StatSoft, Inc.», США) включала дисперсионный анализ (ANOVA), расчет средних значений $(M)$, стандартных ошибок средних ( \pm SEM). Статистическую значимость различий при попарном сравнении вариантов оценивали по $t$-критерию Стьюдента.

Результаты. Сравнение состава мультиконверсионных отходов после культивирования съедобных базидиомицетов (C3 - KLePo) с таковым у промышленного субстрата, используемого для культивирования L. edodes $(\mathrm{C} 1-\Pi L e)$, а также у низинного торфа (табл. 1$)$ показало, что субстратную основу лабораторных образцов мультибиоконверсионных препаратов можно охарактеризовать как органическое удобрение, которое содержит доступные углеводы, полученные при разложении базидиомицетами целлюлозы и лигнина, которые входили в состав $\mathrm{C1}$, с увеличенным содержанием азота и белка и сниженным соотношением C:N (см. табл. 1).

1. Состав конверсионного шиитачно-вешеночного субстрата (KLePo), полученного в результате последовательного культивирования Lentinula edodes (шиитаке) и Pleurotus ostreatus (вешенки) на растительных техногенных отходах, в сравнении с промышленным субстратом для культивирования шиитаке (ПLe) и низинным торфом $(M \pm \mathrm{SEM}$, полупромышленное культивирование)

\begin{tabular}{|c|c|c|c|}
\hline Компонент & $\Pi L e^{(a)}$ & $\mathrm{KLePo}(\mathrm{c})$ & Низинный торф (b) \\
\hline \multicolumn{4}{|c|}{ Доля от абсолютно сухой массы субстрата, \%: } \\
\hline целлюлоза & $36,5 \pm 1,2^{* * *}(\mathrm{a} / \mathrm{c})$ & $16,7 \pm 0,3^{* *}(\mathrm{c} / \mathrm{b})$ & $15,6 \pm 0,3$ \\
\hline лигнин & $24,3 \pm 3,4 *(\mathrm{a} / \mathrm{c})$ & $17,3 \pm 0,5$ & $22,1 \pm 0,4^{* * *}(\mathrm{~b} / \mathrm{c})$ \\
\hline общий белок & $2,7 \pm 0,3$ & $9,4 \pm 0,3 * * *(\mathrm{c} / \mathrm{b} ; \mathrm{c} / \mathrm{a})$ & $4,3 \pm 0,1$ \\
\hline общий азот & $0,4 \pm 0,1$ & $1,5 \pm 0,3 * * *(\mathrm{c} / \mathrm{b} ; \mathrm{c} / \mathrm{a})$ & $0,6 \pm 0,1$ \\
\hline аминный азот & $0,3 \pm 0,1$ & $1,2 \pm 0,1 * * *(\mathrm{c} / \mathrm{b} ; \mathrm{c} / \mathrm{a})$ & $0,1 \pm 0,02$ \\
\hline зола & $13,5 \pm 3,2^{* * *(a / c)}$ & $2,5 \pm 1,6$ & $3,7 \pm 0,3$ \\
\hline \multicolumn{4}{|c|}{ Количество от абсолютно сухой массы субстрата, мг/кг: } \\
\hline незаменимые аминокислоты & $14,1 \pm 2,3$ & $14,3 \pm 9,9$ & $9,2 \pm 0,1$ \\
\hline пул аминокислот & $32,4 \pm 10,3$ & $31,4 \pm 16,7$ & $22,9 \pm 0,1$ \\
\hline $\mathrm{Ca}$ & $1343,1 \pm 228,7$ & $1465,4 \pm 351,7$ & $2625,3 \pm 52,8^{* * *}(\mathrm{~b} / \mathrm{c})$ \\
\hline $\mathrm{Na}$ & $157,4 \pm 10,2$ & $189,3 \pm 57,2$ & $380,3 \pm 28,2^{* * *}(\mathrm{~b} / \mathrm{c})$ \\
\hline $\mathrm{K}$ & $3089,3 \pm 32,4$ & $2643,5 \pm 321,2^{* * *}(\mathrm{c} / \mathrm{b})$ & $1250,1 \pm 28,9$ \\
\hline $\mathrm{Mn}$ & $454,1 \pm 89,6$ & $581,8 \pm 185,6$ & $360,8 \pm 85,4$ \\
\hline $\mathrm{Fe}$ & $329,6 \pm 59,8$ & $278,3 \pm 87,2$ & $208,8 \pm 21,1$ \\
\hline биотин & $0,03 \pm 0,01$ & $0,04 \pm 0,01 * * *(\mathrm{c} / \mathrm{b} ; \mathrm{c} / \mathrm{a})$ & $0,02 \pm 0,00$ \\
\hline тиамин & $0,3 \pm 0,1$ & $0,5 \pm 0,1$ & $0,6 \pm 0,0$ \\
\hline рибофлавин & $1,7 \pm 0,3$ & $4,3 \pm 0,1^{* * *}(\mathrm{c} / \mathrm{b} ; \mathrm{c} / \mathrm{a})$ & $3,1 \pm 0,2$ \\
\hline $\mathrm{C}: \mathrm{N}$ & 81,2 & 38,3 & 92,9 \\
\hline
\end{tabular}

П р и м е ч а н и е. Описание субстратов (ПLe, KLePo, низинный торф) см. в разделе «Методика».

*, **, *** Различия между KLePo и ПLe (c/a; a/c) и между КLePo и низинным торфом (b/c; с/b) статистически значимы соответственно при $\mathrm{p} \leq 0,10 ; \mathrm{p} \leq 0,05$ и $\mathrm{p} \leq 0,01$.

Количество питательных компонентов для развития штаммов-продуцентов T. asperellum Т-36 и B. subtilis B-10 в мультиконверсионном шиитачно-вешеночном субстрате достоверно ( $\mathrm{p} \leq 0,01)$ превышало эти показатели для низинного торфа, который обычно используется как субстрат для твердофазного получения биопрепаратов. Содержание общего азота и белка было выше в 2,0 раза, микроэлементов и витаминов - в 1,5-2,0 раза, 
легкодоступных углеводов - в 1,5 раза (см. табл. 1).

В результате твердофазного культивирования на C3 (KLePo) были получены мультиконверсионные биопрепараты на основе $T$. asperellum $\mathrm{T}$ 36 и B. subtilis В-10 с титром биоагентов $10^{10} \mathrm{KOE} / г$.

При тестировании эффективности этих препаратов в полевых условиях против фитофтороза картофеля вегетация растений проходила при среднемесячной температуре и относительной влажности воздуха в мае соответственно $13,1{ }^{\circ} \mathrm{C}$ и $67,2 \%$; в июне $-19,8{ }^{\circ} \mathrm{C}$ и 70,1 \%; в июле $24,4{ }^{\circ} \mathrm{C}$ и $68,5 \%$; в августе $-19,1{ }^{\circ} \mathrm{C}$ и $69,2 \%$. За вегетационный сезон 2011 года зафиксировали 42 солнечных дня. Полевые испытания мультиконверсионных биопрепаратов, проведенные в течение одного вегетационного сезона, выявили в начале вегетации достоверное ( $\mathrm{p} \leq 0,01)$ усиление скорости роста и облиственности растений картофеля в 1,2 раза под воздействием обоих экспериментальных лабораторных образцов по сравнению с эффектом только базовых агротехнических и защитных мероприятий (без биопрепаратов). Урожай здоровых клубней при применении биопрепаратов на основе штаммов B. subtilis B-10 и T. asperellum Т-36 был достоверно $(\mathrm{p} \leq 0,10)$ выше контроля соответственно на 240 и 690 г/м ${ }^{2}$ (табл. 2).

2. Биометрические показатели развития растений картофеля сорта Елизавета в течение одной вегетации под воздействием экспериментальных лабораторных образцов мультиконверсионных биопрепаратов на основе Trichoderma asperellum T-36 и Bacillus subtilis B-10 (M士SEM, ПК «Шушары», Ленинградская обл., 2011 год)

\begin{tabular}{|c|c|c|c|c|c|}
\hline \multirow[t]{2}{*}{ Вариант } & \multicolumn{2}{|c|}{$\begin{array}{l}\text { Средняя скорость роста } \\
\text { растений, мм/сут }\end{array}$} & \multicolumn{2}{|c|}{$\begin{array}{l}\text { Скорость увеличения } \\
\text { облиственности, ярусов } \\
\text { листьев/сут }\end{array}$} & \multirow{2}{*}{$\begin{array}{l}\text { Урожайность } \\
\text { здоровых клубней, } \\
\text { кГ } / \text { м }^{2}\end{array}$} \\
\hline & 1-2-й ярус & 9-10-й ярус & 1-2-й ярус & 9-10-й ярус & \\
\hline А $3 \mathrm{M}+$ ЛО Т-36 ШВ, Г & $1,65 \pm 0,05^{* *}$ & $10,61 \pm 0,32^{* * *}$ & $0,17 \pm 0,01^{* * *}$ & $\pm 0,01$ & \\
\hline 0 ШВ, Г & $1,51 \pm 0,04$ & $12,71 \pm 0,27^{*}$ & $0,15 \pm 0,01$ & $0,31 \pm 0,01^{* * *}$ & \\
\hline БАЗМ (контроль) & $1,49 \pm 0,04$ & $12,09 \pm 0,36$ & $0,15 \pm 0,01$ & $0,26 \pm 0,01$ & $4,88 \pm 0,32$ \\
\hline
\end{tabular}

П р и м е ч а н и е. БАЗМ - базовые агротехнические и защитные мероприятия; ЛО Т-36 ШВ, Г - лабораторные образцы мультиконверсионного гранулированного биопрепарата на основе T. asperellum T-36, ЛО В-10 ШВ, Г - лабораторные образцы мультиконверсионного гранулированного биопрепарата на основе B. subtilis B-10 (образцы получены с использованием конверсионного шиитачно-вешеночного субстрата).

*, **, *** Различия с контролем статистически значимы соответственно при $\mathrm{p} \leq 0,10 ; \mathrm{p} \leq 0,05$ и $\mathrm{p} \leq 0,01$.

3. Поражение фитофторозом в период цветения и масса пораженных клубней у картофеля сорта Елизавета при применении экспериментальных лабораторных образцов мультиконверсионных биопрепаратов на основе Trichoderma asperellum T-36 и Bacillus subtilis B-10 (M士SEM, ПК «Шушары», Ленинградская обл., 2011 год)

\begin{tabular}{|c|c|c|c|c|c|}
\hline \multirow[t]{2}{*}{ Вариант } & \multicolumn{2}{|c|}{$\begin{array}{l}\text { Распространенность } \\
\text { фитофтороза, \% }\end{array}$} & \multicolumn{2}{|c|}{ Развитие фитофтороза,\% } & \multirow{2}{*}{$\begin{array}{l}\text { Масса пораженных } \\
\text { клубней, кг/м² }\end{array}$} \\
\hline & $\mathrm{H}$ & $\mathrm{O}$ & $\mathrm{H}$ & $\mathrm{O}$ & \\
\hline БАЗМ + ЛО & $13,8 \pm 0,7^{*}$ & $16,1 \pm 0,6^{*}$ & $1,7 \pm 0,7^{*}$ & $3,6 \pm 0,9^{*}$ & $0,16 \pm 0,04 *$ \\
\hline БАЗМ + ЛО & $14,9 \pm 0,4^{*}$ & $18,6 \pm 0,2^{*}$ & $2,1 \pm 0,3^{*}$ & & $03^{*}$ \\
\hline БАЗМ (контроль) & $57,5 \pm 1,8$ & $62,7 \pm 3,2$ & $10,1 \pm 3,6$ & $26,3 \pm 2,4$ & $0,30 \pm 0,03$ \\
\hline \multicolumn{6}{|c|}{$\begin{array}{l}\text { П р и м е ч а н и е. Н - начало цветения, О - окончание цветения; БАЗМ - базовые агротехнические и } \\
\text { защитные мероприятия; ЛО Т-36 ШВ, Г- лабораторные образцы мультиконверсионного гранулиро- } \\
\text { ванного биопрепарата на основе T. asperellum Т-36, ЛО В-10 ШВ, Г- - лабораторные образцы мультикон- } \\
\text { версионного гранулированного биопрепарата на основе B. subtilis В-10 (образцы получены с использова- } \\
\text { нием конверсионного шиитачно-вешеночного субстрата). } \\
\text { * Различия с контролем статистически значимы при р } \leq 0,01 \text {. }\end{array}$} \\
\hline
\end{tabular}

Применение экспериментальных образцов мультиконверсионных биопрепаратов на основе B. subtilis B-10 и T. asperellum Т-36 достоверно ( $\mathrm{p} \leq 0,01)$ уменьшило распространенность (соответственно в 3,4 и 3,9 раза) и снизило развитие фитофтороза картофеля (в 7,2 и 11,6 раза). По сравне- 
нию с контролем масса пораженных клубней, в том числе с признаками вторичной бактериальной инфекции, достоверно $(\mathrm{p} \leq 0,01)$ уменьшилась почти в 2,0 раза (соответственно на 140 и 130 г/м²) (табл. 3).

4. Эффективность лабораторных образцов новых мультиконверсионных биопрепаратов на основе Trichoderma asperellum T-36 и Bacillus subtilis B-10 против фитофтороза при 1-кратном применении на фоне базовых агротехнических и защитных мероприятий (сорт картофеля Елизавета, ПК «Шушары», Ленинградская обл., 2011 год)

\begin{tabular}{|c|c|c|}
\hline Вариант & $\begin{array}{l}\text { Биологическая } \\
\text { эффективность, \% }\end{array}$ & $\begin{array}{l}\text { Биологическая эффективность } \\
\text { относительно контроля, \% }\end{array}$ \\
\hline \multicolumn{3}{|r|}{74,7} \\
\hline БАЗМ + ЛО В & \multicolumn{2}{|l|}{81,4} \\
\hline БАЗМ (контроль) & \multicolumn{2}{|l|}{38,3} \\
\hline \multicolumn{3}{|c|}{$\begin{array}{l}\text { П р и м е ч а н и е. БАЗМ - базовые агротехнические и защитные мероприятия; ЛО Т-36 ШВ, Г- лабо- } \\
\text { раторные образцы мультиконверсионного гранулированного биопрепарата на основе T. asperellum Т- } 36 \text {, } \\
\text { ЛО В-10 ШВ, Г - лабораторные образцы мультиконверсионного гранулированного биопрепарата на } \\
\text { основе B. subtilis В-10 (образцы получены с использованием конверсионного шиитачно-вешеночного } \\
\text { субстрата). }\end{array}$} \\
\hline
\end{tabular}

Биологическая эффективность системы защиты растений на картофеле сорта Елизавета в условиях промышленного комплекса, включающая внесение удобрений и стимуляторов роста, уничтожение сорной растительности, а также многократное применение химических фунгицидов, не достигала 40 \% (табл. 4). Низкая эффективность традиционных защитных мероприятий обусловлена нарастанием устойчивости популяций возбудителей заболеваний к применяемым химическим пестицидам, которая отмечается в последние годы вследствие антропогенной трансформации агроэкосистем и ухудшения их фитосанитарного состояния $(1,26,31)$.

Применение экспериментальных лабораторных образцов предлагаемых нами мультиконверсионных биопрепаратов увеличило общую биологическую эффективность базовых защитных мероприятий более чем в 2,2 раза (см. табл. 4). Эффективность образцов мультиконверсионных препаратов на основе T. asperellum Т-36 и B. subtilis B-10 на фоне агротехнических мероприятий и защитных химических обработок была достаточно высокой (соответственно 74,7 и 69,8 \%) (см. табл. 4).

Большинство биопрепаратов на основе B. subtilis и T. asperellum, зарегистрированных в России и рекомендованных для защиты картофеля от болезней в период вегетации, имеют титры соответственно $10^{9}-10^{11}$ и $10^{8}$ $10^{10} \mathrm{KOE}$ в расчете на 1 г или 1 мл (в зависимости от препаративной формы) (1, 12). У двух новых экспериментальных мультиконверсионных образцов титр составил $10^{10} \mathrm{KOE} / г$, что соответствует таковому у зарегистрированных аналогов - Алирина Б, ТАБ; Алирина Б, СП; Алирина Б, Ж; Глиокладина, ТАБ; Глиокладина, СК; Глиокладина, СП; Глиокладина, Ж; Трихоцина, СП (все препараты производства ООО «Управляющая компания «АБТ-групп» и ФГБНУ ВИЗР, Россия) $(30,32)$. Известно, что отработанные при промышленном культивировании съедобных грибов субстраты успешно используются в сельском хозяйстве как органические удобрения $(36,37)$. В том числе такие отходы хорошо зарекомендовали себя в качестве удобрений и стимуляторов роста при выращивании картофеля (38). Разработанный при выполнении этого исследования субстрат, который представляет собой продукт двухэтапной биоконверсии целлюлозо- и лигнинсодержащих промышленных и сельскохозяйственных отходов съедобными базидиомицетами (шиитаке и вешенка) - это полноценное органическое удобрение, обогащенное микроэлементами и витаминами $(25,36)$. Отмеченное в нашем исследовании увеличение биометрических показателей растений картофеля и рост урожайности, а также повышение эффек- 
тивности традиционной интегрированной защиты картофеля открывают перспективу разработки биопрепаратов защитного назначения, сочетающих в себе также свойства биоудобрений и биостимуляторов (39-43). Применение экспериментальных образцов полифункциональных биопрепаратов на основе $T$. asperellum Т-36 и B. subtilis В-10 в полевых условиях в принятых нормах расхода обеспечило достоверный защитный эффект, соответствующий описанному в мировых разработках у аналогичных препаратов (44-47).

Таким образом, нами показана возможность получения экологически безопасных гранулированных биопрепаратов, наиболее удобных для внесения в почву, посредством мультибиоконверсии растительных производственных отходов с помощью съедобных грибов и штаммов-продуцентов полифункциональных биопрепаратов. Получены новые данные о питательной ценности субстратов, отработанных при выращивании на них съедобных грибов, при повторном использовании для твердофазного культивирования продуцентов биопрепаратов. Доказано, что одно применение экспериментальных образцов новых мультиконверсионных биопрепаратов на основе Bacillus subtilis B-10 и Trichoderma asperellum Т-36 повышает эффективность общепринятых базовых мероприятий по защите картофеля от фитофтороза соответственно на 70 и $75 \%$.

\section{ЛИТ ИРАТ УРА}

1. Зейрук В.Н., Кузьмичев А.А., Глез В.М., Деревягина М.К., Васильева С.В., Абашкин О.В. Фитосанитарное состояние и мероприятия по борьбе с основными болезнями и вредителями в период вегетации и хранения картофеля. М., 2014.

2. Kubicek C.P., Komon-Zelazowska M., Druzhinina I.S. Fungal genus Hypocrea/Trichoderma: from barcodes to biodiversity. Zhejiang University Science B, 2008, 9(10): 753-763 (doi: 10.1631/jzus. B0860015).

3. Reino L.R., Raul F., Hernandez-Galan G.R., Collado I.G. Secondary metabolites from species of the biocontrol agent Trichoderma. Phytochemistry Reviews, 2008, 7: 89-123 (doi: 10.1007/s11101006-9032-2).

4. Moradi H., Bahramnejad B., Amini J., Siosemardeh A., Haji-Allahverdipoor K. Suppression of chickpea (Cicer arietinum L.) Fusariums wilt by Bacillus subtilis and Trichoderma asperellum. Plant Omics Journal, 2012: 68-74.

5. $\mathrm{Ru}$ Zh., Di W. Trichoderma spp. from rhizosphere soil and their antagonism against Fusarium sambucinum. African Journal of Biotechnology, 2012, 11(18): 4180-4186 (doi: 10.5897/AJB11.3426).

6. Kubicek C.P., Mach R.L., Peterbauer C.K., Lorito M. Trichoderma: from genes to biocontrol. Journal of Plant Pathology, 2001, 83: 11-23.

7. Benítez T., Rincon F.M., Limon M.C., Codon A.C. Biocontrol mechanisms of Trichoderma strains. International Microbiology, 2004, 7(4): 249-260 (doi: 10.2436/im.v7i4.9480).

8. Актуганов Г.Э., Галимзянова Н.Ф., Мелентьев А.И., Кузьмина Л.Ю. Внеклеточные гидролазы штамма Bacillus sp. 739 и их участие в лизисе клеточных стенок микромицетов. Микробиология, 2007, 76: 471-479 (doi: 10.1134/S0026261707040054).

9. Чеботарь В.К., Макарова Н.М., Шапошников А.И., Кравченко Л.В. Антифунгальные и фитостимулирующие свойства ризосферного штамма Bacillus subtilis Ч-13 - продуцента биопрепаратов. Прикладная биохимия и микробиология, 2009, 45(4): 465-471 (doi: 10.1134/S0003683809040127).

10. Аринбасарова А.Ю., Баскунов Б.П., Меденцев А.Г. Низкомолекулярный антимикробный пептид из Trichoderma cf. aureoviride Rifai BKMF-4268D. Микробиология, 2017, 86(2): 258260 (doi: 10.7868/S0026365617020057).

11. Коломиец Э.И., Бусько И.И., Ананьева И.Н., Абакшонок В.С. Биологическая эффективность препарата Бактосол против клубневых гнилей картофеля при хранении. Картофелеводство, 2013, 21(1): 220-227.

12. Джалилов Ф.С. Биологические препараты против болезней растений. Картофель и овощu, 2018, 8: 2-4 (doi: 10.25630/PAV.2018.8.18269).

13. Коломбет Л.В., Жиглецова С.К., Дербышев В.В., Ежов Д.В., Косарева Н.И., Быстрова Е.В. Микофунгицид - препарат на основе Trichoderma viride для борьбы с болезнями растений. Прикладная биохимия и микробиология, 2001, 37(1): 110-114.

14. Заика Н.А., Громовых Т.И., Ушанова В.М. Перспективы использования растительных субстратов для получения биопрепаратов защиты сеянцев хвойных. В сб.: Лесной и хи- 
мический комплексы - проблемы и решения (экологические аспекты). Красноярск, 2004, 3: 34-37.

15. Sánchez C. Modern aspects of mushroom culture technology. Applied Microbiology and Biotechnology, 2004, 64(6): 756-762 (doi: 10.1007/s00253-004-1569-7).

16. Sánchez C. Cultivation of Pleurotus ostreatus and other edible mushrooms. Applied Microbiology and Biotechnology, 2010, 85(7): 1321-1337 (doi: 10.1007/s00253-009-2343-7).

17. Chitamba J., Dube F., Chiota W.M., Handiseni M. Evaluation of substrate productivity and market quality of oyster mushroom (Pleurotus ostreatus) grown on different substrates. International Journal of Agricultural Research, 2012, 7(2): 100-106 (doi: 10.3923/ijar.2012.100.106).

18. Li C., Chen C., Wu X., Tsang C.-W., Mou J., Yan J., Liu Y., Lin C.S.K. Recent advancement in lignin biorefinery: with special focus on enzymatic degradation and valorization. Bioresource Technology, 2019, 291: 121898 (doi: 10.1016/j.biortech.2019.121898).

19. Djarwanto, Tachibana S. Screening of fungi capable of degrading lignocellulose from plantation forests. Pakistan Journal of Biological Sciences, 2009, 12: 669-675 (doi: 10.3923/pjbs.2009.669.675).

20. Chukwurah N.F., Eze S.C., Chiejina N.V., Onyeonagu C.C., Ugwuoke K.I., Ugwu F.S.O., Nkwonta C.G., Akobueze E.U., Aruah C.B., Onwuelughasi C.U. Performance of oyster mushroom (Pleurotus ostreatus) in different local agricultural waste materials. African Journal of Biotechnology, 2012, 11(37): 8979-8985 (doi: 10.5897/AJB11.2525).

21. Čvančarová M., Křesinová Z., Filipová A., Covino S., Cajthaml T. Biodegradation of PCBs by ligninolytic fungi and characterization of the degradation products. Chemosphere, 2012, 88(11): 1317-1323 (doi: 10.1016/j.chemosphere.2012.03.107).

22. Jafarpour M., Eghbalsaeed S. High protein complementation with high fiber substrates for oyster mushroom cultures. African Journal of Biotechnology, 2012, 11(14): 3284-3289 (doi: 10.5897/AJB11.1473).

23. Sales-Campos C., Pires D.A., Barbosa S.R.L., Abreu R.L.S., Andrade M.C.N. In vitro cultivation of Pleurotus ostreatus and Lentinula edodes in lignocellulosic residues from Amazon. African Journal of Biotechnology, 2013, 12(46): 6526-6531 (doi: 10.5897/AJB2013.12854).

24. Титова Ю.А., Хлопунова Л.Б., Федорова Р.А., Зыков И.О. Производство вешенки путем мультибиоконверсии отходов производства шиитаке. В сб.: Современная микология в России. М., 2017, т. 7: 389-391.

25. Титова Ю.А., Долгих В.В., Богданов А.И. Особенности биоконверсии компонентов растительных субстратов штаммами-продуцентами биопрепаратов. Вестник защиты растений, 2014, 3: 46-49.

26. Новикова И.И. Биологическое разнообразие микроорганизмов - основа для создания новых полифункциональных биопрепаратов для фитосанитарной оптимизации агроэкосистем. Вестник защиты растений, 2016; 87(3): 120-122.

27. Титова Ю.А. Методология получения мультиконверсионных биопрепаратов для защиты растений. Мат. ІІІ Всероссийского съезда по защите растений. СПб, 2013, 2: 396-400.

28. Segarra G., Aviles M., Casanova E., Borrero C., Trillas I. Effectiveness of biological control of Phytophthora capsici in pepper by Trichoderma asperellum strain T34. Phytopathologia Mediterranea, 2013, 52(1): 77-83 (doi: 10.14601/Phytopathol_Mediterr-11242).

29. Федоренко В.Ф., Мишуров Н.П., Коноваленко Л.Ю. Современные технологии производства пестицидов и агрохимикатов биологического происхождения. М., 2018.

30. Новикова И.И., Бойкова И.В., Павлюшин В.А., Зейрук В.Н., Васильева С.В., Деревягина М.К. Биологическая эффективность препаративных форм на основе микробовантагонистов для защиты картофеля от болезней при вегетации и хранении. Вестник защиты растений, 2015, 86(4): 12-19.

31. Зейрук В.Н., Васильева С.В., Новикова И.И., Бойкова И.В. Перспективы развития экологически безопасной защиты картофеля. Защита картофеля, 2018, 1: 23-28.

32. Новикова И.И., Титова Ю.А., Бойкова И.В., Зейрук В.Н., Краснобаева И.Л. Биологическая эффективность новых биопрепаратов на основе микробов-антагонистов в контроле возбудителей болезней картофеля при вегетации и хранении клубней. Биотехнология, 2017, 33(6): 68-76 (doi: 10.21519/0234-2758-2017-33-6-68-76).

33. Доспехов Б.А. Методика полевого опыта. М., 1979.

34. Методы экспериментальной микологии: Справочник /Под ред. В.Н. Билай. Киев, 1982.

35. Методические указания по регистрационным испытаниям фунгицидов в сельском хозяйстве. СПб, 2009.

36. Иванов А.И., Корягин Ю.В., Анохин Р.В. Использование отработанного субстрата в качестве органического удобрения - важнейшее звено безотходной технологии выращивания грибов. ХХІ век: итоги прошлого и проблемы настоящего плюс, 2015, 27(5): 120-128.

37. Фомин И.В., Кшникаткин С.А. Производство органического удобрения в виде гранул из отработанного субстрата вешенки. Концепт, 2016, 11: 2791-2795.

38. Польских С.В., Мелькумова Е.А., Федюкина Ю.А., Одиловна Х.К. Влияние отдельных агроприемов и отработанных субстратных блоков вешенки обыкновенной Pleurotus ostreatus Fr. Kumm на формирование урожая поздних сортов картофеля. Вестник Мичуринского ГАУ, 2015, 2: 31-36.

39. Segarra G., Casanova E., Bellido D., Odena M.A., Oliveira E., Trillas I. Proteome, salicylic 
acid, and jasmonic acid changes in cucumber plants inoculated with Trichoderma asperellum strain T34. Proteomics, 2007, 7(21): 3943-3952 (doi: 10.1002/pmic.200700173).

40. Yoshioka Y., Ichikawa H., Naznin H.A., Kogure A., Hyakumachi M. Systemic resistance induced in Arabidopsis thaliana by Trichoderma asperellum SKT-1, a microbial pesticide of seedborne diseases of rice. Pest Management Science, 2012, 68(1): 60-66 (doi: 10.1002/ps.2220).

41. Singh V., Upadhyay R.S., Sarma B.K., Singh H.B. Trichoderma asperellum spore dose depended modulation of plant growth in vegetable crops. Microbiological Research, 2016, 193: 74-86 (doi: 10.1016/j.micres.2016.09.002).

42. Zhang F., Ruan X., Wang X., Liu Z., Hu L., Li C. Overexpression of a chitinase gene from Trichoderma asperellum increases disease Resistance in transgenic soybean. Applied Biochemistry and Biotechnology, 2016, 180(8): 1542-1558 (doi: 10.1007/s12010-016-2186-5).

43. Su S., Zeng X., Bai L., Williams P.N., Wang Y., Zhang L., Wu C. Inoculating chlamydospores of Trichoderma asperellum SM-12F1 changes arsenic availability and enzyme activity in soils and improves water spinach growth. Chemosphere, 2017, 175: 497-504 (doi: 10.1016/j.chemosphere.2017.02.048).

44. Asad S.A., Ali N., Hameed A., Khan S.A., Ahmad R., Bilal M., Shahzad M., Tabassum A. Biocontrol efficacy of different isolates of Trichoderma against soil borne pathogen Rhizoctonia solani. Polish Journal of Microbiology, 2014, 63(1): 95-103.

45. Mahmoud H.E.K., Amgad A.S., Anas E., Younes Y.M. Characterization of novel Trichoderma asperellum isolates to select effective biocontrol agents against tomato Fusarium wilt. The Plant Pathology Journal, 2015, 31(1): 50-60 (doi: 10.5423/PPJ.OA.09.2014.0087).

46. Li Y., Sun R., Yu J., Saravanakumar K., Chen J. Antagonistic and biocontrol potential of Trichoderma asperellum ZJSX5003 against the maize stalk rot pathogen Fusarium graminearum. Indian Journal of Microbiology, 2016, 56(3): 318-327 (doi: 10.1007/s12088-016-0581-9).

47. Qiong W., Ruiyan S., Mi N., Jia Y., Yaqian L., Chuanjin Y., Kai D., Jianhong R., Jie C. Identification of a novel fungus, Trichoderma asperellum GDFS1009, and comprehensive evaluation of its biocontrol efficacy. PLoS ONE, 12(6): e0179957 (doi: 10.1371/journal.pone.0179957).

ФГБНУ Всероссийский НИИ защиты растений, 196608 Россия, г. Санкт-Петербург-Пушкин, ш. Подбельского, 3, e-mail: juli1958@yandex.ru $₫$, irina_novikova@inbox.ru $\bowtie$,

irina_boikova@mail.ru,info@vizr.spb.ru,krasnobaeva08@mail.ru
Поступила в редакцию

29 июня 2019 года

Sel'skokhozyaistvennaya biologiya [Agricultural Biology], 2019, V. 54, № 5, pp. 1002-1013

\title{
NOVEL SOLID-PHASE MULTIBIORECYCLED BIOLOGICS BASED ON Bacillus subtilis AND Trichoderma asperellum AS EFFECTIVE POTATO PROTECTANTS AGAINST Phytophthora DISEASE
}

\section{J.A. Titova, I.I. Novikova, I.V. Boykova, V.A. Pavlyushin, I.L. Krasnobaeva}

\author{
All-Russian Research Institute of Plant Protection, 3, sh. Podbel'skogo, St. Petersburg, 196608 Russia, e-mail \\ juli1958@yandex.ru ( $₫$ corresponding author), irina_novikova@inbox.ru ( $₫$ corresponding author), irina_boi- \\ kova@mail.ru, info@vizr.spb.ru, krasnobaeva08@mail.ru \\ ORCID: \\ Titova J.A orcid.org/0000-0002-8188-1852 \\ Novikova I.I. orcid.org/0000-0003-2816-2151 \\ Pavlyushin V.A. orcid.org/0000-0002-4727-8750 \\ Boykova I.V. orcid.org/0000-0001-6268-7301 \\ Krasnobaeva I.L. orcid.org/0000-0001-9166-4475 \\ The authors declare no conflict of interests \\ Acknowledgements: \\ This work was carried out as part of the Complex Research Program "Development of potato breeding and seed \\ production", Section 9 "Development of effective potato protection technologies". \\ Received June 29, 2019 \\ doi: 10.15389/agrobiology.2019.5.1002eng
}

\section{Abstract}

A total of 17 biologics based on the producer strains Bacillus subtilis and Trichoderma asperellum ( $=T$. harzianum) are currently approved in Russia to protect potatoes from diseases. Great world experience has been gained in producing and use of traditional dry and liquid biologics. However, multirecycled industrial wastes as substrates for biologics are still not used anywhere in the world, and there is little information on effectiveness of formulations produced by industrial wastes' multistage biorecycling. This paper reports a successful experience of the sequential use of plant wastes as substrates for mushrooms and then for microbial strains to produce granular antifungal biologics. This is a relevant approach to biotechnologies for safer utilization of wastes as resources of cheap and affordable raw materials and their transformation into useful products. Our objective was to develop brand new multirecycled biologics based on plant pathogen antagonists and to estimate their efficacy. Plant wastes were converted to substrates for B. subtilis B-10 and T. asperellum T-36 producer strains by shiitake Lentinula edodes (Berk.) Pegler and oyster mushroom Pleurotus ostreatus 
(Jacq.: Fr.) P. Kummer HK-35 serial cultivation. The nutritional value of the obtained double biorecycled substrate, due to decomposition of cellulose and lignin of sawdust and wheat bran mixture by shiitake and oyster mushroom, was higher as compared to that of the initial substrate used for shiitake growing or of peat, a common solid-phase fermentation substrate. In particular, the protein content was higher $(9.4 \pm 0.3 \%$ vs. $2.7 \pm 0.3 \%$ and $4.3 \pm 0.1 \%$, respectively), the nitrogen level was higher $(1.5 \pm 0.3 \%$ vs. $0.4 \pm 0.1 \%$ and $0.6 \pm 0.1 \%)$, and the $\mathrm{C}: \mathrm{N}$ ratio reduced (38.3 vs. 81.2 and 92.9$)$. Liquid microbial inoculums were cultured in standard Czapek (Biocompas-C Ltd., Russia) and cornmolasses (Carguil Ltd., Agroresource Ltd., Russia) nutrient media. Solid-phase fermentation of the double biorecycled lignin- and cellulose-containing substrate inoculated with $0.9 \times 10^{9}$ spores $/ \mathrm{ml}$ B. subtilis $\mathrm{B}-10$ and $2.8 \times 10^{10} \mathrm{CFU} / \mathrm{ml}$ T. asperellum $\mathrm{T}-36$ to produce the biologics took 10 days at $25-28{ }^{\circ} \mathrm{C}$. The obtained biologics were tested on potato cv. Elizaveta in plot trials in the Leningrad Province (Producers' Cooperative Shushary, 2011). A reciprocally orthogonal scheme was used, and the plots were arranged in 4 replicates over 0.5 ha, with $10 \mathrm{~m}^{2}$ test plot size and 482 plants sampled in total. A single application was performed at planting on May 12, 2011. The tubers were mixed with the biologics in the bunker of the potato-planting unit at a rate of $1 \mathrm{~kg}$ per 1.5 ton tubers $(2 \mathrm{~kg} / \mathrm{ha})$. The basic potato growing technology included i) post-planting application of Sencor ${ }^{\circledR}$ herbicide $(800 \mathrm{~g} / \mathrm{l}$, Bayer Crop Science, Germany); ii) post-germination double application (with one-week interval) of Terraflex ${ }^{\circledR} 17 / 17 / 17$ inoculant (2.8 and $1.6 \mathrm{~kg} / \mathrm{ha}$, Nu3 N.V., Belgium); iii) post-germination single application of Aquadon micro inoculant $(2.0 \mathrm{l} / \mathrm{ha}$, Orgpolymersyntes, Russia), Extrasol ${ }^{\circledR}$ microbe fertilizer agent $(2.0$ 1/ha, BisolbyInter Ltd., Russia), Zircon inoculant (10 g/ha, ANO Nest-M, Russia), herbicides Lazurite (0.5 1/ha, AO Avgust, Russia) and Titus ${ }^{\mathrm{TM}}$ (20 g/ha, DuPont, USA); and iv) treatments with fungicides after row closure as follows: Bravo ${ }^{\circledR}$ (1.5 1/ha, Syngenta AG, Switzerland) and Ridomil gold ${ }^{\circledR}$ (1.5 1/ha, Syngenta AG, Switzerland) in 2 weeks; Revus ${ }^{\circledR}\left(250 \mathrm{~g} / \mathrm{ha}\right.$, Syngenta AG, Switzerland) in 4 weeks, and Shirlan ${ }^{\circledR}(0.4$ 1/ha, Syngenta AG, Switzerland) in 6 weeks. The final fertilization with Terraflex ${ }^{\circledR}(2.8 \mathrm{~kg} / \mathrm{ha})$ combined with Shirlan ${ }^{\circledR}$ treatment $(0.4$ l/ha) were carried out 2 weeks before harvesting. The basic agrotechnology without biologics served as the control. Standard biometric and phytopathological indicators were used. The disease signs and biometric parameters were assessed in 3-week seedlings (1-2 leaf layer phase) and at row closure. Then two disease surveys were performed at the beginning and at the end of blooming, and final indicators for tubers were estimated at harvesting. Data processing by ANOVA and Student's $t$-test for pairwise comparison revealed that the biologics caused a significant increase in plant growth rate and the leaf area growth at the beginning of vegetation. The healthy tuber yield was 240 and $690 \mathrm{~g} / \mathrm{m}^{2}$ higher for $B$. subtilis B-10 and T. asperellum T-36 biologics, respectively, as compared to the control $(\mathrm{p} \leq 0.10)$. Due to the biologics, the late blight intensity was 7.2 times lower and 11.6 times lower, respectively $(\mathrm{p} \leq 0.01)$. The number of affected tubers, including those with signs of secondary bacterial infection, decreased almost 2 times, by 140 and $130 \mathrm{~g} / \mathrm{m}^{2}$, respectively ( $\mathrm{p} \leq 0,01)$. Thus, solid plant waste multirecycling is a prospective way to produce granular environmentally safe biologics for plant protection against diseases. In the developed three-step technology, the wastes from edible mushroom double cultivation on sawdust mixed with wheat bran possess high nutritional value as a substrate for solid microbial cultures.

Keywords: multirecycled biologics, efficacy, potato, diseases, protection, microbial antagonists, multirecycling, Bacillus subtilis, Trichoderma asperellum.

\section{Научные собрания WORLD BIOTECHNOLOGY CONGRESS 2020}

(February 20-21, 2020, Valencia, Spain)

Biotechnology Congress aims to create a bridge between academia and industry by providing vast learning opportunities in multidisciplinary sectors and applied fields of Biotechnology.

The World Biotechnology Congress 2020, Valencia Spain will offer a unique opportunity for both the academic and industry stakeholders to meet and interact. This International Biotechnology Conference will be the best platform for young researchers to meet the world-class scientists, policymakers, industry experts to network and share the knowledge. Biotechnology 2020 will be the key source of knowledge for the budding minds and inspire them to build their career in the vast sector of Biotechnology and allied fields.

The sessions of the Conference will mainly focus on the applied sectors of Biotechnology to discuss the recent trends, challenges, advancements and discoveries in multidisciplinary applied segments of Biotechnology, i.e. applications of Biotechnology in Agriculture to healthcare, Pharmaceuticals, Food security, Livestock development, but not limited to Genomics, Agricultural Biotechnology, Pharmaceutical Biotechnology, Micro Biology, Molecular Biology, Immunology, Cancer and Epigenetics studies, Food Biotechnology, Clinical Microbiology, Ethics and IPR in Biotechnology, Biosensors and their applications, Molecular and Cell Biology, Biochemistry, Industrial Biotechnology, Animal Biotechnology, Environmental application of Biotechnology etc.

Information: https://www.hilarisconferences.com/biotechnology 